DOI: 10.46340/eujem.2021.7.6.4

\title{
Olha Rudenok
}

ORCID ID: https://orcid.org/0000-0002-2001-400X

Vasyl' Stus Donetsk National University, Vinnytsia, Ukraine

\section{METHODOLOGICAL BASICS \\ OF USING THE OWNERSHIP CONCENTRATION IN THE VBM-SYSTEM OF CORPORATIONS}

The corporation becomes the interest satisfaction center of various groups of stakeholders in market conditions. Given all these interests, the company is interested in long-term activities, improvement, and development. The main purpose of the corporation is to maximize its value, which contributes to the well-being of its owners. Value-based management combines classic approaches to business valuation and modern tools to maximize the market value of the corporation. The company's value management is quite relevant. It is growing in connection with the increasing competition of the corporations in the struggle for the capital of shareholders and investors. Also, the need for value management is related to the current requirements for doing business. The ownership concentration is an important tool of corporate governance. It enables shareholders to control the corporations in which they invest, and thus to influence the corporation value. In the article are defined the methodological bases of using the ownership concentration in the system of value-based management. An important part of value management is understanding the determinants of performance, which are the basis for value creation. The article considers the models of corporations, namely the shareholder model and the stakeholder model. The relationship of stakeholders with the corporation activities is systematized using the graphical method. It is determined that the ownership concentration is accompanied by private benefits in the hands of the blockholder. So, it is these private benefits that influence the decisions of the controlling shareholder. The features and directions of the impact of the corporation's ownership concentration on its value were determined as a result of the system analysis, synthesis, and generalization of value drivers.

Keywords: value drivers, concentrated ownership, corporation value, Shareholder Model, Stakeholder Model.

Problem setting and its relevance. The value of a corporation plays an important role in increasing the welfare of owners (shareholders). The higher the company's share price, the higher its value. Usually, shareholders are interested in increasing the company value because their profits depend on it. However, corporations face agency problems around the world, i.e., the incompatibility of the interests of owners (shareholders) with managers or majoritarians with minorities. In turn, this inconsistency affects the change in the company value. Concentrated ownership is widespread almost all over the world (through cross-ownership, pyramids, dual-class share structure), which raises the issue of studying the impact of concentrated ownership on value and finding a place of ownership concentration in the value system of corporations.

Literature review and analysis on the research topic. The basic concepts that contain the peculiarities of the functioning of VBM and on which most modern scientific works are based were introduced by economists Rappaport A., McTaggart J. M., Kontes P. W., Mankins M. C., Koller T. The impact of ownership concentration in various aspects on the company value is considered in the works of scientists Choi A. H., Kong Y., Famba T., Chituku-Dzimiro G., Sun H., Kurauone O., Vintila G., Gherghinaa S. C., Venusita L., Agustia D., Utomo M.N., Wahyudi S., Muharam H., Helmina M.R.A., Bottenberg K., Tuschke A., Flickingeretc M.

The purpose of the article is to study and systematize the effects of ownership concentration on the corporation's value. Analysis of existing drivers of increasing the value of the company in order to determine the direction of the impact of concentrated ownership on value.

Presentation of the main research material. A corporation will be profitable only when all costs are covered including borrowed capital and equity costs. The idea of management based on value has emerged 
and formed in the last years. This concept has attracted the scientists' interest after the publication in 1986 of the work entitled "Creating Shareholder Value: The New Standard for Business Performance", authored by Alfred Rappaport. The book "The Value Imperative: Managing for Superior Shareholder Returns" (in 1994), authored by James M. McTaggart, Peter W. Kontes, Michael C. Mankins, first used the term "Value-based Management" as a separate definition. Value-based management means a system of processes, principles, and convictions through which corporations succeed in confronting internal institutional requirements and external competitors, which ultimately leads to the company's main goal, according to the above scientific research.

Value-based management (VBM) is a philosophical attitude to management, where the main thing is to ensure the companies' management, based on their value (mainly maximizing shareholder value), given the interest of owners (shareholders) in the process of their implementation. This approach to management covers the processes of creating, managing, and measuring value ${ }^{3}$.

In a general sense, a company's value is the benefits (available and possible) that a company can receive, expressed in the form of value, which is determined through the use of certain models and methods.

According to the concept of value management, the reduced future cash flows to the present value determine the value of the company. The value creation process occurs when corporations invest capital with a return that is greater than the value of the capital invested. Deepening these visions, VBM focuses on how corporations apply them in making both day-to-day tactical and important long-term decisions ${ }^{3}$.

The important component of VBM is understanding the performance variables that actually create value, i.e., key value drivers. The value drivers are considered to be the variable on which the value of the company depends in some way. There are seven common value drivers that are used in all organizations in the economic literature (Figure 1).

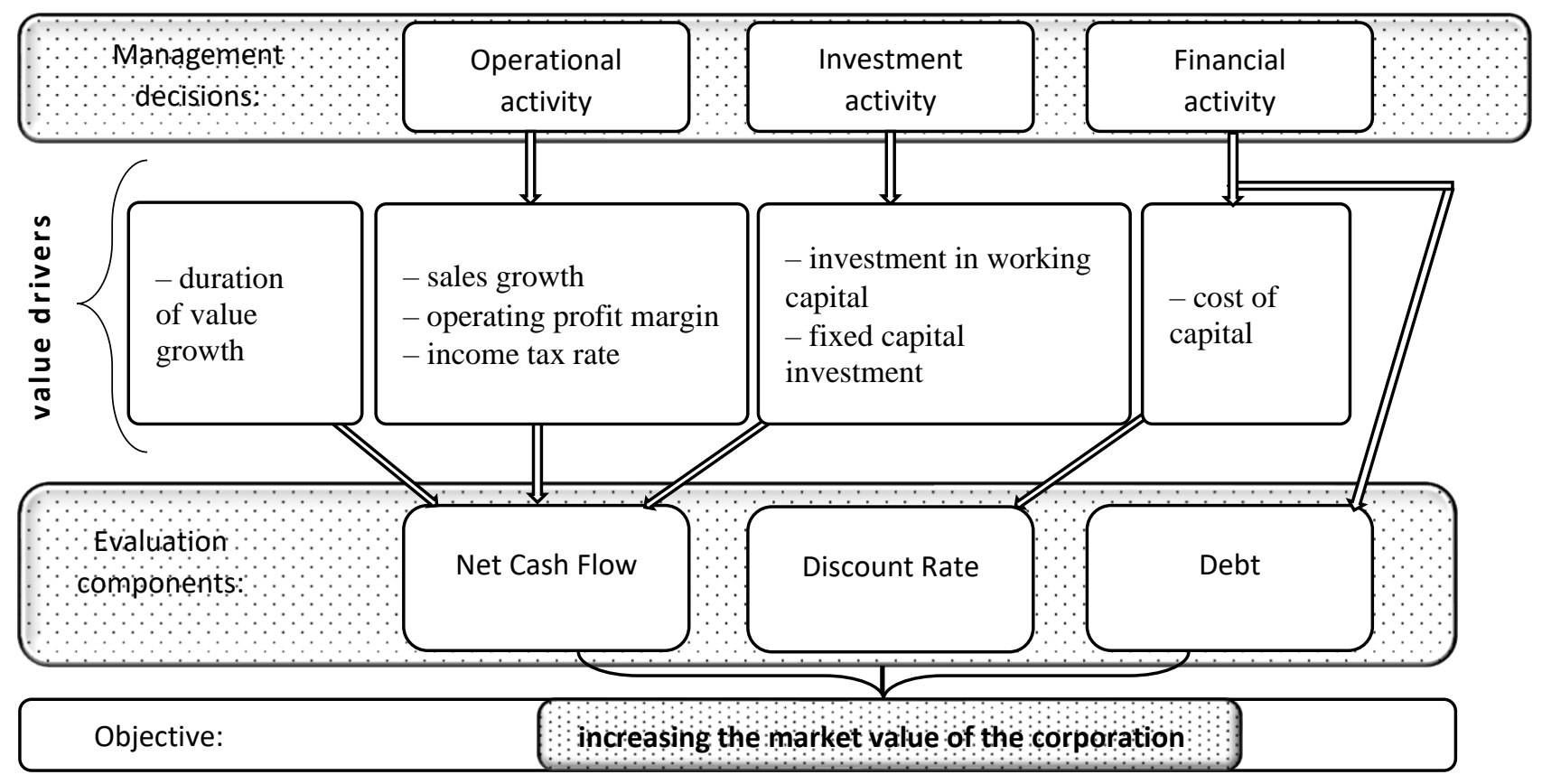

Fig. 1. Drivers to increase the market value of the corporation ${ }^{4}$

\footnotetext{
${ }^{1}$ Rappaport, A. (1986). Creating Shareholder Value: The New Standard for Business Performance.

New York: Free press.

${ }^{2}$ McTaggart, J. M., Mankins, M. C., Kontes, P. W. (1994). The Value Imperative: Managing for Superior Shareholder

Returns. New York: Free press.

${ }^{3}$ Koller, T. (1994). What is value-based management? McKinsey Quarterly <https://www.mckinsey.com/businessfunctions/strategy-and-corporate-finance/our-insights/what-is-value-based-management> (2021, October, 30).

${ }^{4}$ Petravicius, T., Tamosiuniene, R. (2008). Corporate Performance and The Measures of Value Added. Transport,

23(3), 194-201. DOI: https://doi.org/10.3846/1648-4142.2008.23.194-201.
} 
It is worth emphasizing that the "value" is a comprehensive indicator, which includes the full information about the company's activities, covering all stages of the production and commercial cycle. This is a reason to say that the value of a corporation should be investigated not only as a result of evaluation but also as an object of management. Corporate value management is the process of making and implementing management decisions aimed at increasing the income of owners through increasing the market value of shares. Thus, the essence of the corporation's value-oriented policy is a comprehensive and holistic model. This model contributes to the fact that the activities of corporations are aimed at growing value. That is based on the formation of the provided behavior of participants in corporate relations and future conditions, based on the existing company potential.

VBM depends on corporate purpose and corporate values. Based on existing scientific discussions on the link between corporative management and company efficiency, two different models have been distinguished ${ }^{1}$ : Shareholder and Stakeholder Models.

In essence, all shareholders are stakeholders, but not all stakeholders are shareholders (Figure 2).

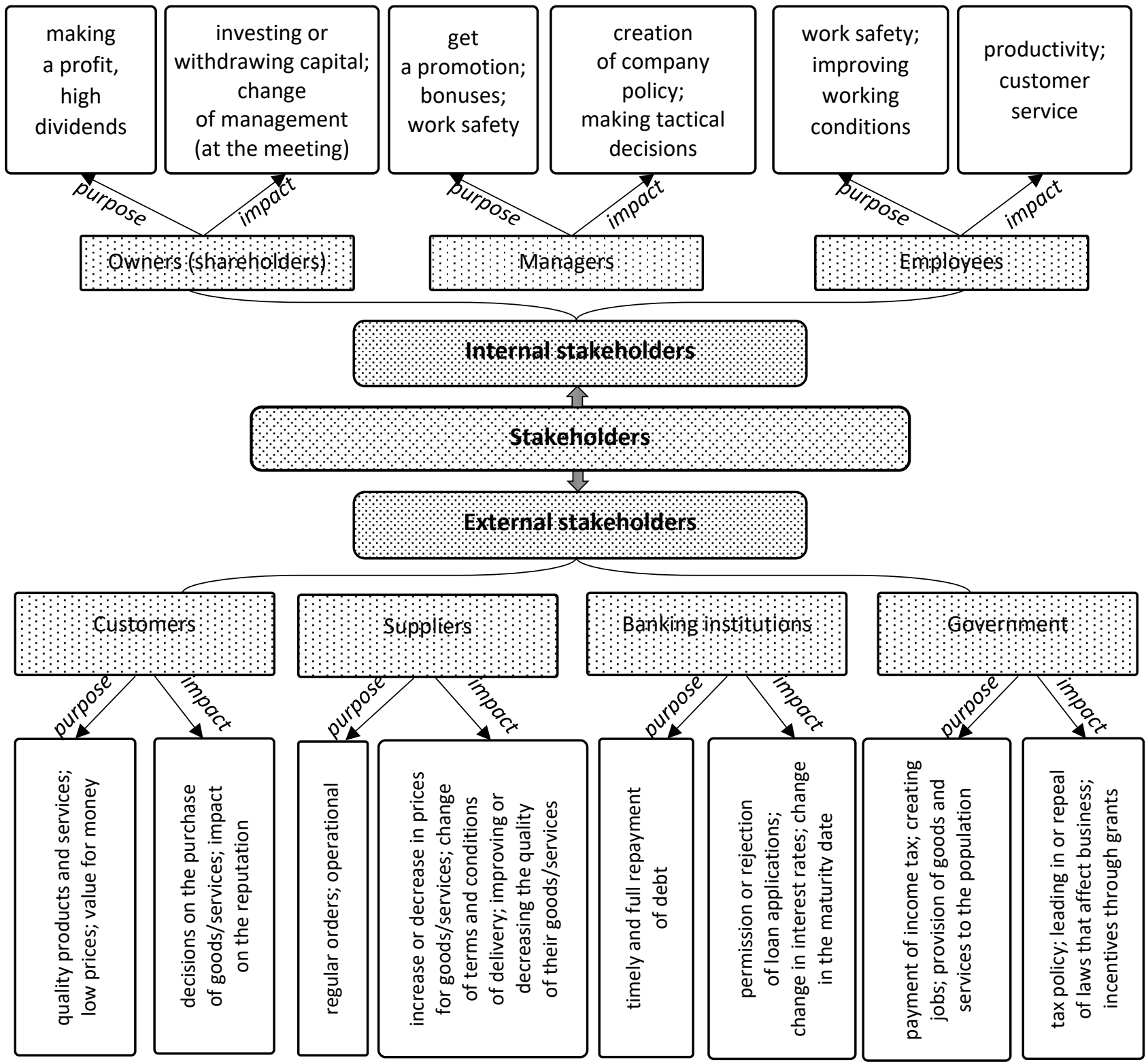

Fig. 2. The relationship of stakeholders with the company

Resource: built by the author

\footnotetext{
${ }^{1}$ Bottenberg, K., Tuschke, A., Flickingeretc, M. (2017). Corporate Governance Between Shareholder and Stakeholder Orientation: Lessons from Germany. Journal of Management Inquiry, 26 (2), 165-180.
} 
According to Shareholder Model, the goal is maximizing the wealth of shareholders, i.e., maximizing profits. The criterion of effectiveness is the market value (shareholder value) of the company.

The Stakeholder Model considers the interests of those groups and individuals who may influence or suffer from the company's activities. Efficiency is assessed by a broader group interested in employment, market share, and the growth of trade relations with counterparties, as well as in financial results.

Each model has its own characteristics ${ }^{12}$. The shareholder model describes the corporate purpose and corporate values in the narrow sense, i.e., what concerns the interests of only the shareholders themselves. The practice of countries with market economies provides convincing evidence that the long-term growing corporation value determines the sustainable and strategic activities of the corporation, increases the welfare of its owners, and socio-economic development of the country (Figure 3).

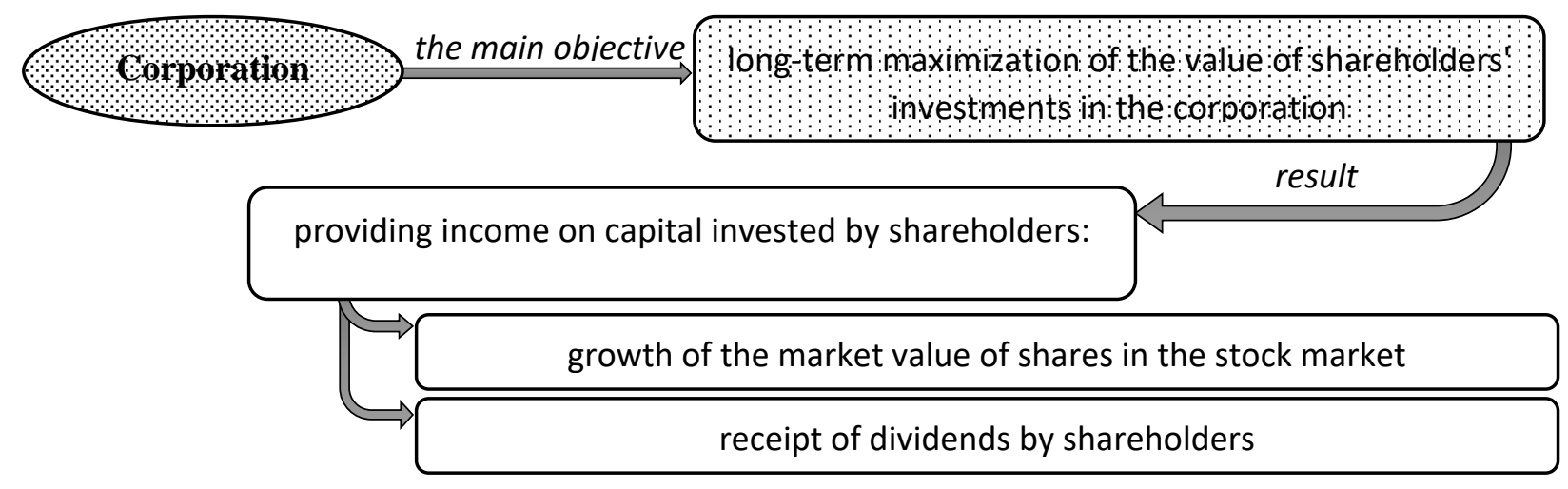

Fig. 3. The main objective of corporations (by Shareholder Model)

Resource: built by the author

The "principal-agent" relationship arises as a result of distribution ownership and control. It is the main problem of corporate governance in the shareholder model. This distribution leads to the fact that the corporations do not achieve the aim of maximizing their value ${ }^{1}$.

The shareholder approach to corporate management is somewhat narrowly focused, which is first of all reflected in the coordination of the interests of owners and managers. However, it should be noted that shareholders are not the only ones who invest in the corporation. The efficient operation and competitiveness of a corporation are all the result of the joint work of all stakeholders. In general, economic performance and corporate governance will depend on the relationship between different categories of stakeholders ${ }^{3}$.

Coordination competing requirements of shareholders and other stakeholders is a major problem faced by managers of all companies. There is a growing worldwide interest in the approach of stakeholders to management, that concentrates on achieving strategic aims. Given the possible results of corporate governance for economic activity, it is worth considering that companies are responsible not only to shareholders but also to other parties. Support from different stakeholder groups contributes to the value creation process. Working together to achieve many of the company's goals is a key way for stakeholders to achieve some of their own goals, even though their intentions and interests may be very different. The impact that different stakeholder groups can have on the efficiency and behavior of a corporation, as well as on economic growth is important. According to the concept of the Stakeholder Model, stakeholders are participants who have contributed company-specific assets ${ }^{4}$.

\footnotetext{
${ }^{1}$ Bottenberg, K., Tuschke, A., Flickingeretc, M. (2017). Corporate Governance Between Shareholder and Stakeholder Orientation: Lessons from Germany. Journal of Management Inquiry, 26 (2), 165-180.

${ }^{2}$ Koller, T. (1994). What is value-based management? McKinsey Quarterly <https://www.mckinsey.com/businessfunctions/strategy-and-corporate-finance/our-insights/what-is-value-based-management> (2021, October, 30).

${ }^{3}$ Kong, Y., Famba, T., Chituku-Dzimiro, G., Sun, H., Kurauone, O. (2020). Corporate Governance Mechanisms, Ownership and Firm Value: Evidence from Listed Chinese Firms. International Journal of Financial Studies, 8, 20; DOI: $10.3390 /$ ijfs8020020.

${ }^{4}$ Choi, A. 3H. (2018). Concentrated Ownership and Long-Term Shareholder Value. Harvard Business Law Review, 8 , 53-99.
} 
The Stakeholder Model demonstrates the corporate goal and values in a broader sense, i.e., with the desire to meet the needs of all stakeholders and at the same time increase the company efficiency. The stakeholder approach is an extended version of the Shareholder Model. Note that one of the consequences of opportunistic behavior is that in general, it leads to insufficient investment. The principal-agent relationship is key in the shareholder model and is just one of many areas in which this is happening. Insufficient investment is related to investments of suppliers, customers, employees, etc., in the stakeholder model. The key challenge is to find ways to operate that will help minimize the effects of opportunism and expropriation, while at the same time allocating resources efficiently and increasing investment ${ }^{1}$.

The Shareholder Model generates rules that facilitate the work of managers to formulate priority areas of activity and introduces a system for assessing the effectiveness (profitability) of the corporation, which is the advantage of this model. However, the Stakeholder Model also has its advantages. First of all, the priority is to eliminate the problem of underinvestment caused by opportunism, as well as to promote effective cooperation of stakeholders in order to provide long-term profitability of the corporation.

The methodological approach in determining the place of concentration of ownership in the value management system is to highlight the fact that when thinking about concentrated ownership in corporations, it is necessary to take into account the behavior of the controlling shareholder to simultaneously influence the overall activities of the corporation. The first aspect emphasizes the need to carefully study the interaction of the company and the controlling shareholder in the commodity market. The second aspect focuses on the interaction of majoritarians with minorities in the financial market ${ }^{2}$.

Concentrated ownership mostly involves the presence of private benefits in the hands of the controlling shareholder at the expense of minorities. Nevertheless, there are many examples of companies with concentrated ownership and the presence of a controlling shareholder, which are quite successful (Meta (Facebook), BMW, Amazon, Fiat, Lego, Ikea, Samsung, Google) ${ }^{2}$. In this case, the question arises how to explain the effectiveness of companies, if the presence of a controlling shareholder leads to private benefits from the company and minority shareholders.

There is a problem of short-term coordination of incentives and long-term commitments between the controlling shareholder and the company (Figure 4).

It is more likely that the controlling shareholder will be interested in the long-term value of the corporation, as private preferences grow (especially when they are illiquid and non-transferable). While the ownership concentration provides a basis for the controlling shareholder to obtain certain private benefits through minority interests, it also enables the majority shareholder to realize the "idiosyncratic" value that is useful to meet the needs of all shareholders. There are claims about the need for private benefits, to compensate for the majority of its actions aimed at growth, in the economic literature. But on the other hand, there is also a drawback: in the case where the controlling shareholder receives a large number of private benefits, it can reduce his interest in increasing the corporation's efficiency. The reason for this is that most of the profits of the majority shareholder are formed from private benefits that do not depend on the company's profits.

Therefore, it is acceptable that the controlling shareholder receives private benefits on the way to maximizing the long-term corporation value.

After all, the size of private benefits cannot be too large to completely reduce the incentive to maximize the company value.

At the same time, private benefits should not be too small, because in this case, the shareholder will have no long-term relationship with the corporation, and it can be easy to liquidate his position.

All participants, including consumers on the goods and services market and financial market investors, expect the majority shareholder to have a long-term interest in the company once the right balance of private benefits has been struck. That will facilitate the necessary investment.

At the same time, research shows that the impact of ownership concentration on the corporation value is not monotonous ( $\cap$-shaped impact of ownership concentration on the corporation value). In the sense that a high degree of ownership concentration does not always give better results (Figure 5).

\footnotetext{
${ }^{1}$ Kong, Y., Famba, T., Chituku-Dzimiro, G., Sun, H., Kurauone, O. (2020). Corporate Governance Mechanisms, Ownership and Firm Value: Evidence from Listed Chinese Firms. International Journal of Financial Studies. 8, 20; DOI: $10.3390 /$ ijfs 8020020 .
} 


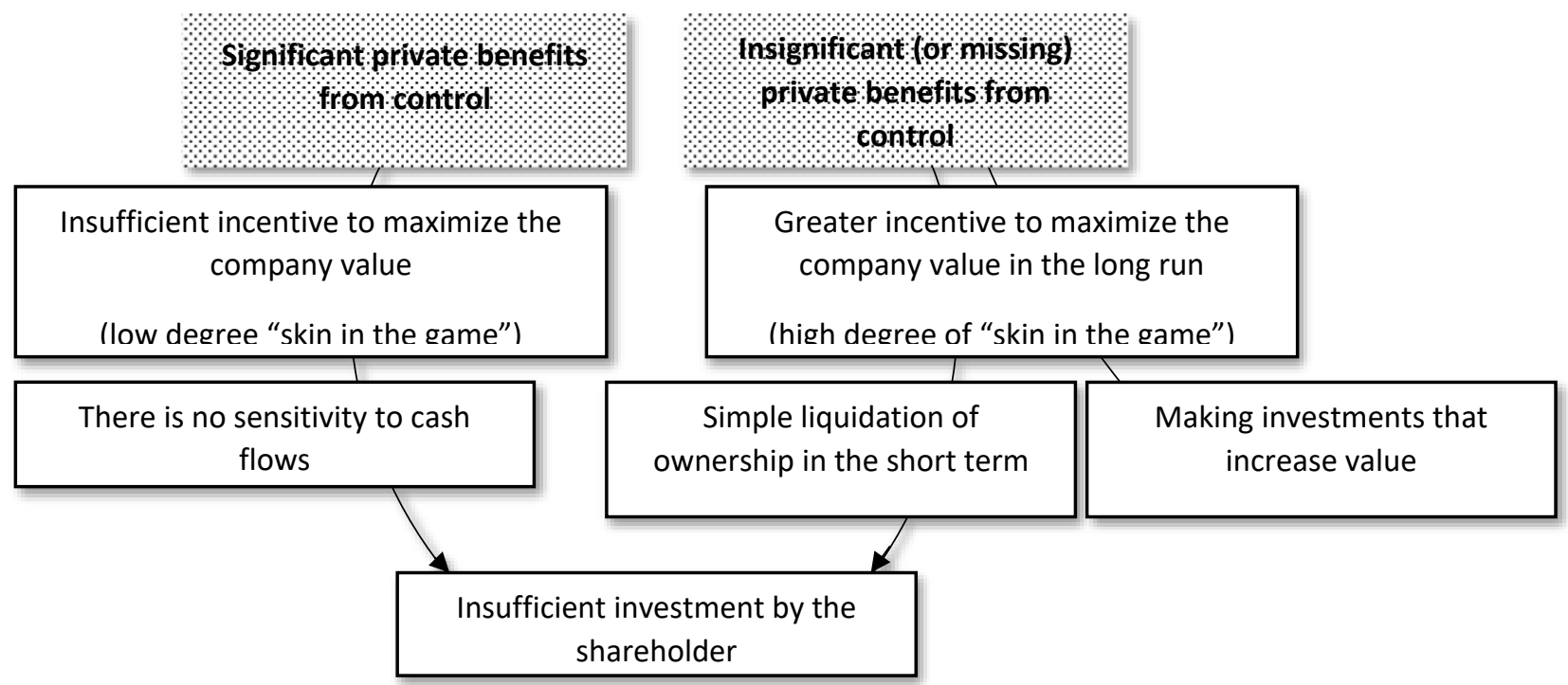

Fig. 4. The impact of private benefits on the decisions of controlling shareholders

Resource: built by the author

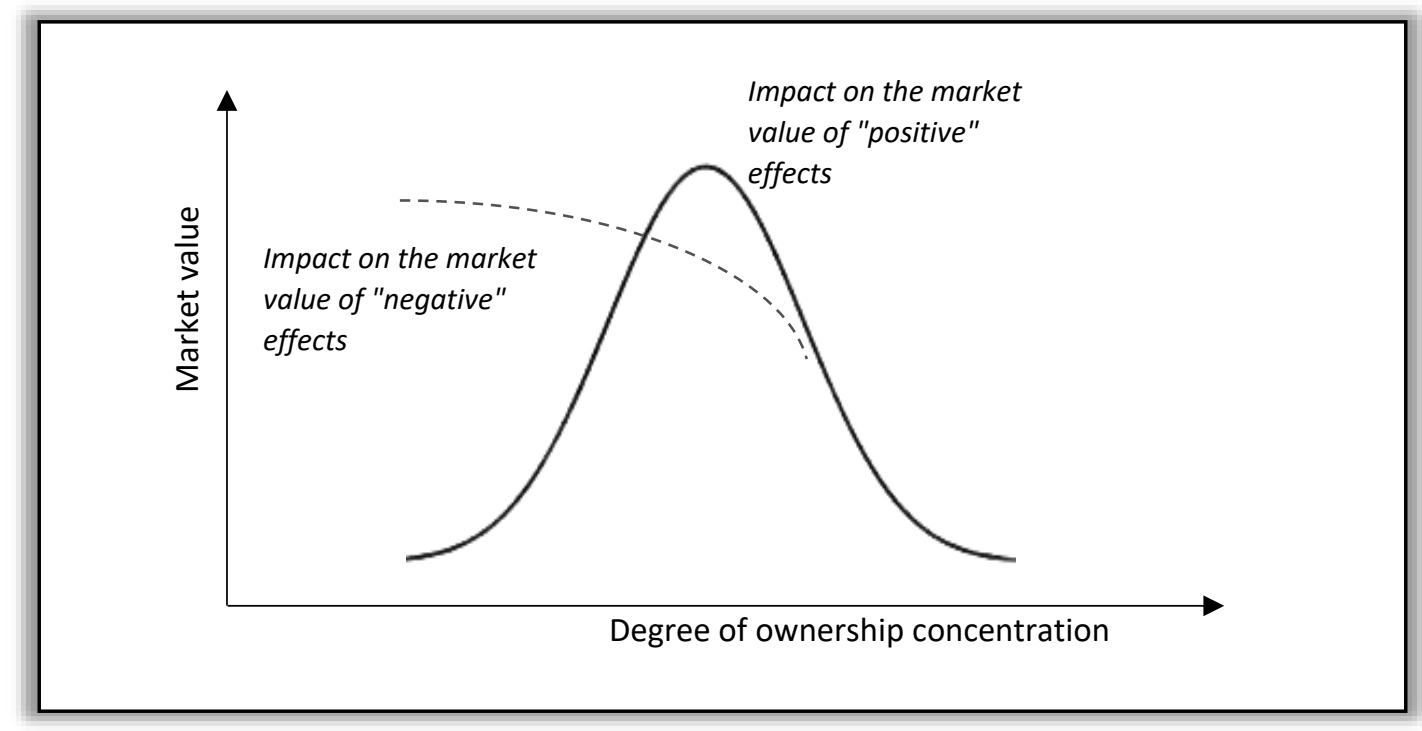

Fig. 5. Graphic representation of the impact of ownership concentration on the corporation market value

Resource: built by the author

The result suggests that the initial increase in company ownership stimulates the shareholder. A further increase in the ownership concentration reduces the value, due to the majority of major private benefits.

Some scientific research suggests that as a shareholder's share of ownership grows, the corporation value may also increase, while the overall trend is declining. Companies with a controlling shareholder are more adaptable and less dependent on external factors.

The corporation value to some extent depends on the impact of the positive and negative effects of concentrated ownership (Figure 6). 


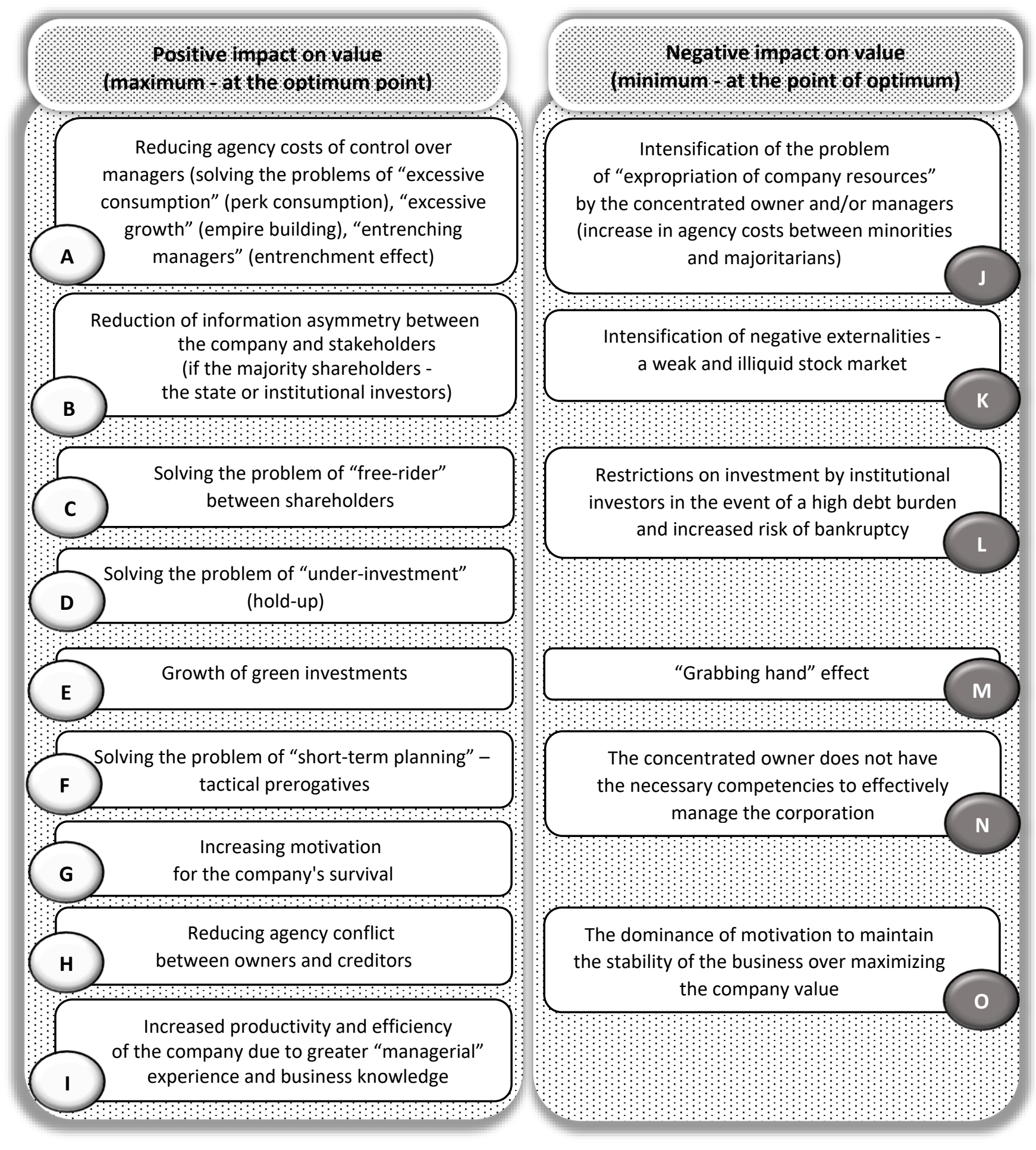

Fig. 6. The impact of ownership concentration on the corporation value

\section{Resource: built by the author}

It should be noted that concentrated ownership solves the problem of "principal-agent" through direct monitoring by the shareholder, considering the positive impact. Because the lack of control over management can lead to opportunistic behavior of managers. Agency costs are reduced, and concentrated ownership should lead to better efficiency by providing better incentives for monitoring, as a result of solving this problem.

The positive impact of concentrated ownership (in the case of concentrated institutional or state ownership) on the corporation value is a reduction in agency costs due to minimizing the asymmetry of information between the corporation and stakeholders. Institutional investors applicate of professional 
knowledge, highly developed managerial skills, and voting rights to influence managers. Using the opportunities of institutional investors in terms of their access to capital in financing the corporation and the effect of "helping hand" by the state in case of adverse circumstances and market conjuncture are also positive impacts.

Incentives to monitor governance are weak. That is one of the main difficulties with dispersed ownership. Shareholders hope that other shareholders will do the monitoring. This is because the benefits of monitoring are shared among all shareholders, while all monitoring costs are borne by those who monitor. The problem of "free-rider" does not arise in concentrated corporations, as the majority shareholder receives most of the benefits associated with his monitoring efforts. Thus, the problem of corporate governance does not primarily concern the general protection of shareholders or monitoring issues for a corporation with concentrated ownership ${ }^{1}$.

One of the economic consequences of the possibility of rent expropriation (or opportunistic behavior) of managers is that it reduces the number of resources that investors are willing to invest in company finance. This problem is better known as the "hold-up" problem. Ownership concentration reduces the opportunistic behavior of managers, which leads to an effective level of investment, which, in turn, can have positive consequences for the value of the corporation.

Corporations with corporate activities that are involved in solving social and environmental problems have easier access to sources of capital that can potentially help them increase value. Ownership concentration increases the value of the company indirectly through the improvement of environmental performance. Environmentally friendly management strategy is practically a determining factor for increasing the value of the corporation (Tobin's Q) ${ }^{2}$.

The agency conflict between owners and creditors is that shareholders have the potential to pass on losses to creditors. Thus, shareholders may decide to invest capital (own and/or borrowed) in projects that are riskier than the level of risk that creditors focus on. This level of risk is often the risk of the company's current operations, based on which creditors provide funds and require in return a certain level of profitability. Ownership concentration helps to reduce the agency conflict between owners and creditors and to avoid violating the principle of risk compensation ${ }^{3}$.

On the other hand, the ownership concentration can lead to a new problem that can negatively affect the corporation value. This problem is named the problem of "principal-principal" (conflict of interest between majorities and minorities). Holders of large blocks of shares will take opportunistic behavior against minority shareholders to their advantage, using the power to control monetary and non-monetary benefits through the consolidation effect. Increased concentration of ownership is associated with a lower value.

A negative effect that affects the value of a company is the "grabbing hand". It results from the dominance of fiscal and political interests by the government (concentrated owners) over the interests of the corporation. Because the government will reap most of the profits in favor of politicians when the government owns the company.

The loss of market value of the corporation may be due to inefficient management by the concentrated owner (lack of necessary competencies in managing the corporation), risk aversion and underinvestment in the corporation, low level of innovation, the dominance of motivation to maintain business sustainability over maximizing company value.

Determining the positive and negative effects of concentrated ownership on the value of the corporation makes it possible to identify areas of influence of these effects (Figure 7). In a general sense, the above positive and negative effects have a corresponding impact on net cash flow from operating activities, the amount of investment, and the cost of capital, which in turn leads to an increase or decrease in the market value of the company.

Thus, net cash flow from operating activities is an indicator of the amount of cash received from operating activities of the company and operating cash flows. The importance of the indicator is reflected in the ability of the company to generate a positive cash flow sufficient to meet its obligations, as well as to support and develop its activities without the need for external financing.

\footnotetext{
${ }^{1}$ Vintila, G., Gherghinaa, S. C. (2014). The Impact of Ownership Concentration on Firm Value. Empirical Study of The Bucharest Stock Exchange Listed Companies. Procedia Economics and Finance, 15, 14, 271-279.

${ }^{2}$ Utomo, M. N., Wahyudi, S., M., Helmina, M.R.A. (2019). Linking Ownership Concentration to Firm Value: Mediation Role of Environmental Performamnce. Journal of Environmental Management and Tourism, X, 1 (33), 182-194. DOI:10.14505/jemt.v10.1(33).18.

${ }^{3}$ Venusita, L., Agustia, D. (2021). The Relationship Between Firm Value and Ownership of Family Firms: A Case Study in Indonesia. Journal of Asian Finance, Economics and Business, 8, 4, 863-873.
} 


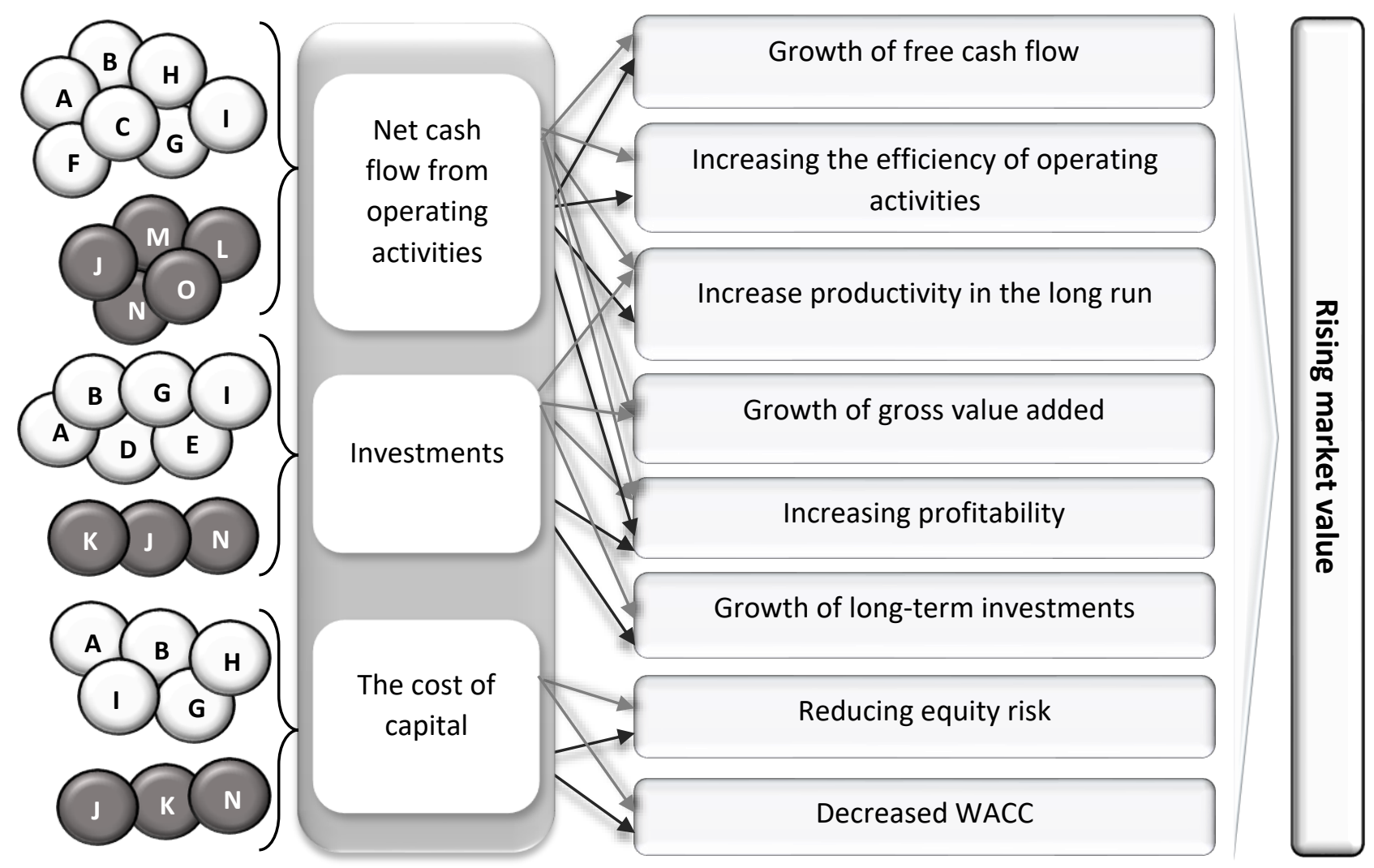

\section{Fig. 7. Directions of influence of positive and negative effects of ownership concentration on the corporation market value}

\section{Resource: built by the author}

Market value is the basis for investment, financing, and many other corporate decisions. In particular, investment considerations include an assessment of how such investments affect the average cost in the long run. The value is created from the difference between the invested capital and the present value of future net cash flows from these investments. When investments bring in more returns than the cost of capital, the value of the company increases, and on the contrary.

Direct impact on the weighted average cost of capital (WACC) has financing decisions. The size of the WACC depends on the proportion of equity and debt. That is why, changing the capital structure of the corporation, can change the value of the weighted average cost of capital. The value of WACC is important for the company because reducing this indicator increases the company's market value and maximizes the welfare of shareholders.

Conclusion. Thus, in the VBM-system the ownership concentration occupies an important place as a tool of corporate governance. Research and systematization of factors that contribute to the growth of value (value drivers) give grounds to argue that the ownership concentration has an indirect impact on the corporation value. Concentrated ownership is accompanied by the presence of a majority shareholder's private benefits, the volume of which depends on the influence of the owner on the corporation's activities. Corporations with concentrated ownership can show both positive and negative effects on value, but positive effects also do not always maximize value. The indirect positive and negative impact of the ownership concentration on the corporation value should be considered through such drivers as net cash flow from operating activities, the amount of investment, and the cost of capital.

\section{References:}

1. Rappaport, A. (1986). Creating Shareholder Value: The New Standard for Business Performance. New York: Free press. [in English].

2. McTaggart, J. M., Mankins, M. C., Kontes, P. W. (1994). The Value Imperative: Managing for Superior Shareholder Returns. New York: Free press. [in English]. 
3. Koller, T. (1994). What is value-based management? McKinsey Quarterly <https://www.mckinsey.com/businessfunctions/strategy-and-corporate-finance/our-insights/what-is-value-based-management> (2021, October, 30). [in English].

4. Petravicius, T., Tamosiuniene, R. (2008). Corporate Performance and The Measures of Value Added. Transport, 23 (3), 194-201. DOI: https://doi.org/10.3846/1648-4142.2008.23.194-201. [in English].

5. Bottenberg, K., Tuschke, A., Flickingeretc, M. (2017). Corporate Governance Between Shareholder and Stakeholder Orientation: Lessons from Germany. Journal of Management Inquiry, 26 (2), 165-180. [in English].

6. Kong, Y., Famba, T., Chituku-Dzimiro, G., Sun, H., Kurauone, O. (2020). Corporate Governance Mechanisms, Ownership and Firm Value: Evidence from Listed Chinese Firms. International Journal of Financial Studies, 8 , 20; DOI: 10.3390/ijfs8020020. [in English].

7. Choi, A. H. (2018). Concentrated Ownership and Long-Term Shareholder Value. Harvard Business Law Review, 8, 53-99. [in English].

8. Vintila, G., Gherghinaa, S. C. (2014). The Impact of Ownership Concentration on Firm Value. Empirical Study of The Bucharest Stock Exchange Listed Companies. Procedia Economics and Finance. 15, 14, 271-279. [in English].

9. Utomo, M. N., Wahyudi, S., M., Helmina, M. R. A. (2019). Linking Ownership Concentration to Firm Value: Mediation Role of Environmental Performamnce. Journal of Environmental Management and Tourism, X, 1 (33), 182-194. DOI: 10.14505/jemt.v10.1(33).18. [in English].

10. Venusita, L., Agustia, D. (2021). The Relationship Between Firm Value and Ownership of Family Firms: A Case Study in Indonesia. Journal of Asian Finance, Economics and Business, 8, 4, 863-873. [in English]. 